\title{
Financing of Social Services for Children in Macedonia
}

\author{
Natasha Bogoevska \\ Associate Professor, University of Ss. Cyril and Methodius University, Skopje \\ Faculty of Philosophy, Institute of Social Work and Social Policy \\ Svetlana Trbojevik \\ Associate Professor, University of Ss. Cyril and Methodius University, Skopje \\ Faculty of Philosophy, Institute of Social Work and Social Policy \\ Sofija Georgievska \\ Associate Professor, University of Ss. Cyril and Methodius University, Skopje \\ Faculty of Philosophy, Institute of Social Work and Social Policy
}

\begin{abstract}
Over the last decade the social services sector in Macedonia has been involved in a reform processes in line with the strategic paths towards decentralization, deinstitutionalization and pluralization of social welfare. Children are in the main focus of the reform processes through twofold policy interventions: reduction of child poverty with incentives for improving range and amount of child benefits and advancement of social services for children facing social problems. Additionally, the reform processes were instigated by substantial budgetary allocations for administration of child benefits and delivery of social services for children followed by a critique for inappropriate targeting of children, undeveloped, low quality and expensive services for children mainly organized in massive residential institutions. Whereas, several researches had been carried out with focus on the quality of social services for children and coverage gaps, there is an insufficient evidence and analysis of the costs of services and their budgeting. This analysis is to serve the purpose of filling in the existing data gap through: (1) to map the existing social protection measures for children in Macedonia executed by state, nongovernmental organizations and private service providers; (2) to identify the main mechanisms for financing social services for children and to provide clear insight into state financial support in the social services delivery and alternative child care support arrangements.
\end{abstract}

Keywords: children, social benefits, social services, mechanisms of financing.

\section{Introduction}

Social protection in the Republic of Macedonia is defined as an activity of public interest. According to the Law on Social Protection, social protection represents a system of measures, activities and policies for prevention and overcoming of the basic social risks to which the citizens are exposed to during their life, for reducing poverty and social exclusion and for strengthening citizen's capacity for personal protection. Social protection is realized through measures for social prevention, rights of financial assistance from social protection, non-institutional and institutional protection of persons in a situation of social risk. In addition to the social measures, the state's responsibility for protection of socially vulnerable categories of population is also achieved by undertaking measures in the tax policy, employment, scholarship policy, housing, family protection, health, upbringing and education, and in other areas in accordance with the law.

Social protection, as an area that encompass multiple domains of policies and involves various actors at many levels, is regulated by a substantial primary and secondary legislation. A systematic law that regulates rights and services, as well as the institutional bases for performing social protection, is the Law on Social Protection. The status, rights, obligations and responsibilities of public bodies and other non-state providers of social services are regulated by several laws and bylaws: Law on Organization and Operation of the State Administrative Bodies, Law on Local Self-Government, Law on 
Institutions, Law on Associations and Foundations, Law on Disability Organizations, Law on Administrative Servants, Law on Employees in Public Sector, Law on General Administrative Procedure, etc.

The system is accomplished through professional work in institutions for social protection, implementation of developmental programs depending on beneficiaries' needs and international standards, monitoring and evaluation of the social protection practices.

Macedonian social protection sector is predominantly managed, in terms of organization and service delivery, by the state and the non-governmental sector, independently or, less commonly, in partnership. However, there are several weaknesses related to the development of this sector, which have been identified. They refer to the low quality of services, especially when state-run, inadequate coverage with social services to respond to the needs of different socially vulnerable groups, as well as financial sustainability issues generated by frequent project funding and weak state support to the nongovernmental sector active in the domain of social services (Bogoevska et al, 2017).

\section{Institutional framework of the social protection system}

The state performs social protection of citizens in accordance with the principle of social justice. The state establishes the system of social protection and enables its functioning, provides conditions and measures for conducting social protection activities and develops forms of self-help. The Republic, the municipality, the City of Skopje and the municipalities in the City of Skopje are carriers of social protection.

\section{1. Relevant governmental and municipal stakeholders}

The Ministry of Labor and Social Policy is the central institution for policy-making, strategic planning, management, and monitoring of legality, especially through inspection over the implementation and enforcement of laws and other regulations in the field of social protection.

The Institute for Social Activities is a public institution that studies social phenomena and promotes social activities. The Institute has its jurisdiction and monitoring over professional work in social protection institutions as well as over other legal and personal entities that perform certain activities in the sector.

In order to accomplish the tasks within the in system a set up social protection institutions have been established: Centers for Social Work and institutions for social protection. Centers for social work are public institutions with public authorization responsible for administration of cash benefits and provision of social services. The CSWs have a key role in the identification of and support of children at risk of being abandoned, in providing support to vulnerable families, and promoting parental care and family reintegration. In addition, CSWs decide on the transfer of a child to alternative care or in being given for adoption and act in these circumstances as legal guardians. Social institutions can be established as institutions for residential care and institutions for non-residential care.

Institutions for residential care for placement of: infants and young children without parents and parental care under the age of three; children without parents and parental care above three years of age and of youth; children and youth with educational and social problems; children and youth with behavioral problems; children and youth with moderate and severe mental disabilities; children and youth with physical disabilities; elderly; adults with physical disabilities; persons with mental disabilities and persons, asylum seekers (Law on Social Protection, Article 115).

Institutions for nonresidential care according to the Law on Social protection are: center for social work, daycare center and clubs for elderly people, daycare center for street children - children on the streets, a daycare center for persons who use or abuse drugs and other psychotropic substances and precursors, a daycare center for people who abuse alcohol or are being treated for alcohol dependence, center for homeless persons, center for persons - victims of domestic violence, center for persons - victims of trafficking, daycare center for persons with mental or physical disability, center for administering assistance at home, center for social rehabilitation of persons that use or abuse drugs and other psychotropic substances and precursors, a small group home and counseling centers (Law on Social Protection, Article 132).

The municipality, the City of Skopje and the municipalities of the City of Skopje provide the realization of social protection through non-residential and residential forms of social protection, housing and raising the awareness of the population for the needs of providing social protection. The municipality, the City of Skopje and the municipalities of the City of Skopje may, in accordance with the material possibilities, determine other rights in the area of social protection, rights in a greater 
extent than the scope of the rights determined by this Law and more favorable conditions for their realization, as well as other forms of social protection. To achieve common interests and to perform joint affairs within the competence, they can merge funds and form joint public services. The cooperation is regulated by the Law on Inter Municipal Cooperation.

\section{Relevant non-governmental stakeholders}

A citizen's associations registered in the Book of records by the Ministry of Labor and Social Policy, and the person who has a work permit issued by the Ministry of Labor and Social Policy may carry out activities in social protection, under the conditions, manner and procedure determined by the Law on social protection. Religious communities, religious groups and their associations registered in the country, can assist persons who have a need of certain types of social protection. Besides public institutions, private institutions for social protections are established with the aim to provide social protection services within the social protection system.

Mapping of the existing NGOs in the Republic of Macedonia which work in protection of the rights of children and vulnerable adult indicates a well develop organizational network with rather equal representation in all regions of the country. Nonetheless, there are several viable stakeholders that play a crucial role in policy making and delivery of social services. Major areas of influence of the NGO sector are promotion and public awareness for the problems of the specific group, advocacy of the rights of vulnerable groups, capacity building of target groups and organizations, analysis of the quality of services as well as identification of implementation gaps and obstacles. Most of them are engaged in immediate work with the vulnerable group offering psychosocial support, legal assistance, and daycare protection and accommodation services. Several organizations have signed contracts with the Ministry of Labor and Social Policy in delivery of services for vulnerable groups such as children without parents and parental care, children and adults with intellectual disabilities. In such cases, as a mechanism for financing services the state uses the payment per capita. Also, on an annual basis the state gives grants for organizations that are registered in the book of registry by the Ministry of Labor and Social Policy. Yet, most of the organizations provide their sustainability through grants and financial aid from foreign donors. Apart from foreign donors, the dominant sources of funding are from government grants, membership fees and activities that generate profit, whereas the lowest share in financing are from individual and businesses donations.

\section{Analysis of public expenditures in social protection}

The activities of the Ministry of Labor and Social Policy for protection of children are implemented in accordance with the annually adopted Program for Social Protection. The activities for protection of children are financed from the budget on social protection ${ }^{1}$. The Budget is divided into three main programs:

Non-institutional social protection. The funds within of this program are designated for activities that are performed by the Center for Social Work, for their organizational units (shelters for the homeless, day care centers for children on the street, for drug users and members of their families as well as for children with disabilities), and for the Institute for Social Activities. Also, some funds are used for cooperation with non-governmental organizations that assist the implementation of deinstitutionalization processes and for the reconstruction and equipment of facilities for non-institutional protection.

Institutional social protection. The funds are directed for accommodation, food, clothing, heating, health care etc. within social institutions, which includes those who provide care of people with physical and psychical disabilities, children without parents, children and youth with learning difficulties and homes for elderly. The funds relate to reconstruction and equipping of facilities for institutional protection.

Compensation and benefits. This includes permanent financial support, social financial support as well as financial support for care and protection. Some of these allowances include benefits for children, benefits for war disabled persons, protection of war veterans and persons with disabilities, right to salary for part-time work for care of child with special needs, oneterm financial assistance and assistance in kind, right to housing, financial support of persons who had a status of a child without parents and parental care until age 18, the right to reimbursement for accommodation costs; as well as accommodation in student homes or other institutions.

Social protection includes expenses regarding the work of social work centers, the Institute for Social Activities, day care centers and shelters, institutional and non-institutional social protection, support and implementation of the Decade and the

1 Overall budget of the Republic of Macedonia for 2017 is 187,612,000 (in thousands of denars). 
Roma Strategy, program for conditional cash transfers, reform of the social protection system and the construction, equipping and maintenance of facilities for social protection. This sector includes compensations and rights in social protection, current transfers to local self-government units for block grants, including measures for reducing poverty. The values are given in thousands MKD1.

Table 1: Planned and rebalanced expenditures for the social protection 2014-2017

\begin{tabular}{|c|c|c|c|c|c|c|c|}
\hline & \multicolumn{7}{|c|}{ Budget year } \\
\hline & \multicolumn{2}{|l|}{2014} & \multicolumn{2}{|l|}{2015} & \multicolumn{2}{|l|}{2016} & \multirow{2}{*}{$\begin{array}{l}2017 \\
\text { Planed }\end{array}$} \\
\hline & Planed & Rebalanced & Planed & Rebalanced & Planed & Rebalanced & \\
\hline $\begin{array}{l}\text { Social } \\
\text { services }\end{array}$ & 1.076 .085 & 1.066 .584 & 1.103 .643 & 1.109 .284 & 1.112 .573 & 1.102 .253 & 1.061 .551 \\
\hline $\begin{array}{l}\text { Rights of } \\
\text { material } \\
\text { assistance } \\
\text { form social } \\
\text { protection }\end{array}$ & 6.520 .637 & 6.816 .278 & 7.472 .840 & 7.800 .760 & 8.235 .069 & 8.213 .499 & 8.515 .047 \\
\hline $\begin{array}{l}\text { Measures fo } \\
\text { reduction } 0 \\
\text { poverty }\end{array}$ & 228.587 & & 235.527 & & 49.304 & & 12.153 \\
\hline $\begin{array}{l}\text { Block } \\
\text { grants for } \\
\text { Local self- } \\
\text { governme } \\
\text { nt }\end{array}$ & 1.160 .536 & 1.160 .536 & 1.193 .474 & 1.193 .474 & 1.303 .285 & 1.303 .285 & 1.420 .000 \\
\hline
\end{tabular}

\section{Source: Ministry of Finance, 2017}

The analysis suggests that the cost of social services in the analyzed period 2014-2017 ranges in relatively same level. Continuous increase was observed in terms of the rate of cash benefits from social and child protection. Namely, from 2014 to 2017 spending on this item increased for $24.92 \%$. Also, a significant increase of $22.36 \%$ occurred regarding block grants to local government (financial resources for transferred competences in child and social protection). There is an evident reduction of $75.35 \%$ in expenses is related to the measures for reduction of poverty in 2017 compared to 2014 .

Table 5 presents the trends of the total planned and rebalanced budget expenditures in the domain of social and child protection for the period 2014-2017.

\section{Table 2: Planned and rebalanced budget expenditures for social and child protection 2014-2017}

\begin{tabular}{|c|c|c|c|c|c|c|c|}
\hline & \multicolumn{7}{|l|}{ Budget year } \\
\hline & \multicolumn{2}{|l|}{2014} & \multicolumn{2}{|l|}{2015} & \multicolumn{2}{|l|}{2016} & 2017 \\
\hline & Planed & Rebalanced & Planed & Rebalanced & Planed & Rebalanced & Planed \\
\hline $\begin{array}{l}\text { Planned } \\
\text { expenditure }\end{array}$ & 33.633 .899 & 34.494 .174 & 34.169 .104 & 36.244 .852 & 39.703 .662 & 39.678 .992 & 41.448 .870 \\
\hline Basic budget & 33.337 .320 & 34.164 .504 & 33.826 .071 & 35.920 .319 & 39.317 .945 & 39.293 .275 & 41.157.473 \\
\hline $\begin{array}{l}\text { Fundraising } \\
\text { activities }\end{array}$ & 78.850 & 78.850 & 78.850 & 63.850 & 59.610 & 59.610 & 59.610 \\
\hline
\end{tabular}

${ }^{1}$ According to the current average exchange rate 1 euro $=61.5764$ denars. 


\begin{tabular}{|l|l|l|l|l|l|l|l|}
$\begin{array}{l}\text { Expenditures } \\
\text { from loans }\end{array}$ & 171.620 & 171.620 & 179.500 & 183.000 & 180.000 & 180.000 & 123.000 \\
\hline $\begin{array}{l}\text { Expenditures } \\
\text { from } \\
\text { donations }\end{array}$ & 32.528 & 64.887 & 55.383 & 48.383 & 121.527 & 121.527 & 84.207 \\
\hline
\end{tabular}

Source: Ministry of Finance, 2017

The analysis of the data indicates a constant increase regarding rebalanced expenditure on social and child protection. The data on expenditures in social and child protection for 2014 compared with the data for 2016 indicates an increase of $15.03 \%$. In the compared years the highest increase of $87.29 \%$ refers to the item of expenditure from donations, while the largest decrease of $24.40 \%$ is in the item of expenditure of fundraising activities.

\section{Table 3: Planned and rebalanced expenditures for child protection 2014-2017}

\begin{tabular}{l|l|l|}
\cline { 2 - 3 } \multicolumn{1}{c|}{ Expenditures for child protection } \\
\cline { 2 - 3 } & Planned expenditures & Rebalanced expenditures \\
\hline 2014 & 55.125 & 52.974 \\
\hline 2015 & 42.845 & 38.723 \\
\hline 2016 & 38.556 & 36.756 \\
\hline 2017 & 39.888 & \\
\cline { 2 - 3 }
\end{tabular}

Source: Ministry of Finance, 2017

The data on child protection refer to expenditures for institutions for child protection and construction, equipping and maintenance of facilities for child protection.

The analysis of the data indicates evident reduction of planned and rebalanced budget expenditures for this item. When 2014 is taken as the base year, the data show that the planned expenditures for child protection in 2017 were reduced for $27.64 \%$. Also, there was an evident decrease of $22.90 \%$ in 2015 and a decreased of $30.61 \%$ in 2016 .

\section{Budgetary allocations for child protection rights}

Law on Child Protection defines a series of child rights such as child supplement, special allowance, parental allowance, right to participation, and one-time financial assistance for newborn.

Child supplement financial assistance aims to cover one portion of the expenses for rising and development of children. Child benefit is realized based on the financial threshold for the income of all family members, until the child reaches the age of 18 yearsand until regular school attendance. Further, it is conditioned that one of the parents has to be employed or to receive unemployment benefits in order to exercises this right. Also, the child supplement is granted to a child without parental care placed in a foster family. The threshold of income is higher for single parents, and the amount differes regarding the level of education. The amounts of compensation has not been changed for several years and amounts 716 MKD per month per for children in preschool and primary education, 1.136 MKD per child in secondary education. Maximum granted amount per family on monthly bases is 1.800 MKD regardless of the number of children. These amounts are adjusted to the living costs in the previous year according to the State Statistical Office. The financial status of the family is established on the basis of the income generated by the family and the total number of family members. When deciding on the child benefit right, the average monthly income of the family is divided by the number of family members. Child benefit may be awarded for children from families with an average monthly income per family member from any source of up to $2.490 \mathrm{MKD}$ and up to $4.980 \mathrm{MKD}$ for children from single parent families.

Special allowance financial assistance is administered to children with specific needs and physical or mental disabilities or combined developmental disabilities under 26 years of age. Special allowance is granted to children with disabilities up to 26 years, the amount of the fee is 4.366 denars, while single parents receive a higher amount. This right shall be exercised without financial threshold. The amount of the special allowance is $4.202 \mathrm{MKD}$. This amount has increased by $50 \%$ for single parents and for $25 \%$ for financially insecure parents, beneficiaries of rights to social financial protection who have children less than 26 years of age with specific needs and physical or mental disabilities or combined developmental disabilities. These amounts are compared and harmonized with the increase in living expenses for the previous year as 
published by the State Statistical Office in January for the current year. Unlike the situation with the child benefit, the data related to the special allowance right is showing an upward trend of increasing numbers of beneficiaries.

One-term financial assistance for a newborn is given to a first-born child as a financial assistance granted to one of the parents, citizen of the Republic of Macedonia with permanent residence in the Republic of Macedonia, for a child born on the territory of the Republic of Macedonia. As first newborn child is considered a first child of the mother by order of birth; more children when the mother during her first delivery gives birth to several children at once (twins, triplets and more); first adopted child or more children when adopted together (twins, triplets and more) during the first adoption, if the child/children is less than one year old and if the mother does not have a first live born child/children by order of birth. The amount of the newborn financial assistance is 4,829 MKD. This amount is compared and harmonized with the increase in living expenses for the previous year as published by the State Statistical Office in January for the current year. This right is awarded regardless of the generated income

Parental allowance right is exercises by mother's who gave birth to a third child after January 2009. Amount of compensation compared to other allowances is very high and amounts to $8.300 \mathrm{MKD}$ per month. The compensation is accomplished until the child reaches the age of 10 years old ${ }^{1}$. Frequent legislative changes had an effect on the overall number of parental allowance beneficiaries. The expectations are that the number of beneficiaries could increase further in the forthcoming years by influx of new beneficiaries (mothers of live born third children), bearing in mind that this right is still applicable.

\section{Table 4: Child rights budget expenses for 2013-2016}

\begin{tabular}{|l|l|l|l|l|} 
& \multicolumn{2}{|l|}{ Budget year } & 2015 & 2016 \\
\hline Total expenses & 2013 & 2014 & 2015 & 3.045 .000 \\
\hline
\end{tabular}

Source: Ministry of Labor and Social Policy, 2017

In the period from 2013 to 2016 , total expenditures for implementation of all financial rights for protection of children have increased for 58.63\% (from 1.918.965 MKD in 2013 to 3.045.000 MKD in 2016, see: Table 7). This is mainly as a result of an increased number of beneficiaries of parental allowance.

\section{Table 5: Number of beneficiaries of child rights for 2013-2016}

\begin{tabular}{|c|c|c|c|c|c|c|c|c|}
\hline \multirow[t]{4}{*}{ Type of right } & \multicolumn{8}{|c|}{ Budget year } \\
\hline & \multicolumn{2}{|c|}{2013} & \multicolumn{2}{|c|}{2014} & \multicolumn{2}{|l|}{2015} & \multicolumn{2}{|l|}{2016} \\
\hline & \multicolumn{2}{|c|}{ Beneficiaries } & \multicolumn{2}{|c|}{ Beneficiaries } & \multicolumn{2}{|c|}{ Beneficiaries } & \multicolumn{2}{|c|}{ Beneficiaries } \\
\hline & Families & Children & Families & Children & Families & Children & Families & Children \\
\hline Child supplement & 8.811 & 17.463 & 8.552 & 17.203 & 7.114 & 14.652 & 5.970 & 12.128 \\
\hline Special allowance & 6.666 & 6.916 & 6.966 & 7.184 & 6.827 & 7.055 & 6984 & 7.245 \\
\hline
\end{tabular}

\footnotetext{
1 The Law on changes and amendments to the Law on Child Protection (Official Gazette of the Republic of Macedonia, number 98/08) prescribed parental allowance payments for: a) second child: monthly payments for a period of 9 months in the amount of $30 \%$ of the average salary paid in the country during the previous year, b) third child: monthly payments for a period of 10 years in the amount of $50 \%$ of the average salary paid in the country during the previous year, c) fourth child: for a period of 15 years in the amount of $70 \%$ of the average salary paid in the country during the previous year, and d) single parental allowance: monthly payment for a period of 15 years in the amount of one average salary paid in the country during the previous year. The average salary was replaced by the average net salary amount with the Law on changes and amendments to the Law on Child Protection (Official Gazette of the Republic of Macedonia 83/09) and the average net salary was replaced by a fixed amount of 8.084 MKD parental allowance for a third child with the Law on changes and amendments to the Law on Child Protection (Official Gazette of the Republic of Macedonia 156/09). As of 01.01.2010, the same Law provided for parental allowance payments of 4.829 MKD for a second child, 8.048 MKD for third, 11.267 MKD for a fourth child and 16.096 MKD for single parental allowance.
} 


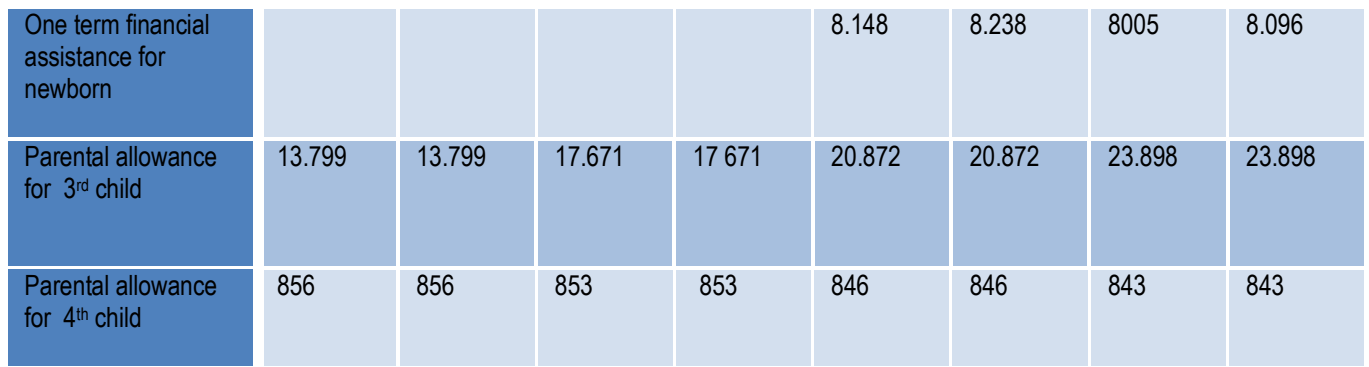

Source: Ministry of Labor and Social Policy, 2017

The number of child supplement beneficiaries has been on a constant decrease for the last few decades. This decrease in the number of child supplement beneficiaries persisted in the analyzed period 2013-2016 when the total number of beneficiaries has dropped from 8.811 beneficiaries (families) with 17.463 children in 2013 to only 5.970 beneficiaries (families) with 12.128 children in 2016. This is a reduction of the number of beneficiaries of $32.24 \%$ and the number of children by $30.55 \%$ in 2016 , in comparison with 2013 . The calculation of the index $(2013=100 \%)$ shows that the total number of beneficiaries in 2016 is just $67.76 \%$ of the total number of beneficiaries in 2013 and the total number of children subject of this right in 2013 is only $69.45 \%$ of the total number of children in 2016 (see Table 6).

\section{Table 6: Movement in the number of child supplement beneficiaries for the period 2013-2016}

\begin{tabular}{|l|l|l|l|l|}
\hline Year & Beneficiaries & $\begin{array}{l}\text { Index } \\
(2013=100 \%)\end{array}$ & $\begin{array}{l}\text { Beneficiaries } \\
\text { (families) }\end{array}$ & $\begin{array}{l}\text { Index } \\
(2013=100 \%)\end{array}$ \\
\hline 2013 & 8.811 & 100.00 & 17.463 & 100.00 \\
\hline 2014 & 8.552 & 97.06 & 17.203 & 98.51 \\
\hline 2015 & 7.114 & 80.74 & 14.652 & 83.90 \\
\hline 2016 & 5.970 & 67.76 & 12.128 & 69.45 \\
\hline
\end{tabular}

Source: Ministry of Labor and social policy

The analysis of special allowance shows a slight but constant growth in the number of beneficiaries. The data show that there were 6.916 children from 6.666 families who were enjoying special allowance right in 2013, while in 2016 this number has increased to 7.245 children from 6.984 families (see Table 7 below). This is an increase of the number of beneficiary families of $4.77 \%$ and the number of children by $4.76 \%$ in 2016 , in comparison with 2013 .

Table 7: Movement in the number of special allowance beneficiaries for the period 2013-2016

\begin{tabular}{|l|l|l|l|l|} 
Year & Beneficiaries & $\begin{array}{l}\text { Index } \\
(2013=100 \%)\end{array}$ & Beneficiaries & $\begin{array}{l}\text { Index } \\
(2013=100 \%)\end{array}$ \\
\hline $\mathbf{2 0 1 3}$ & 6.666 & 100 & (children) & \\
\hline $\mathbf{2 0 1 4}$ & 6.966 & 104,50 & 6.916 & 100 \\
\hline $\mathbf{2 0 1 5}$ & 6.827 & 102,42 & 7.184 & 103,88 \\
\hline $\mathbf{2 0 1 6}$ & 6.984 & 104,77 & 7.055 & 102,01 \\
\hline
\end{tabular}

Source: Ministry of Labor and Social Policy 
The analysis of parental allowance for a third child shows a constant growth in the number of beneficiaries. The data show that there were 13.799beneficiary families who have enjoyed this right in 2013, while in 2016 this number has increased to 23.898beneficiary families (see Review10 below). This is an increase of $73.19 \%$ in 2016, in comparison with 2013.

\section{Review 1: Movement in the number of parental allowance for third child for the period 2013-2016}


\begin{tabular}{|l|l|}
\hline 13.799 & 100,00 \\
\hline 17.671 & 128.06 \\
\hline 20.872 & 151.26 \\
\hline 23.898 & 173.19 \\
\hline
\end{tabular}

2016

23.898

173.19

\section{Source: Ministry of Labor and Social Policy}

\section{Finansig of social services delivery for children}

The social protection system in Macedonia consists of 30 Centers for Social Work and institutions through which social protection is implemented. Social services for children and youth beneficiaries of social protection are are delivered in institutions for: infants and young children without parents and parental care under the age of three; children without parents and parental care above three years of age; children and youth with educational and social problems; children and youth with behavioral problems; children and youth with moderate and severe mental disabilities; children and youth with physical disabilities.

\section{Financing of social protection institutions for children}

The Law on Social Protection determines the ways of financing of public institutions for social protection from the Budget of the Republic of Macedonia. An institution adopts annual operating programs to determine the type, scale, content and quality of services provided to beneficiaries. The program assumes expenses for implementation of activities of the institution, organized in the following items:

Rights for social protection achieved in the institution for social protection, determined by the law,

Salaries based on the law and the collective agreement,

Amortization according to the law,

Material costs,

Maintenance, construction and equipment,

Obligations of the institution determined by law.

The department for financial issues at the Ministry of Labor and Social Policy, based on the submitted financial requirement in a process of consultation with the institution, determines the required funds.

Table 8: Planned budget expenses for social protection institutions for child protection, $2017^{1}$

${ }^{1}$ Annual budget (material expenses) in 2017 varies during the year based on the needs of the institutionand the available budget of MLSP. 


\begin{tabular}{l|l|l|l|l|l|}
\cline { 2 - 6 } & $\begin{array}{l}\text { Planned } \\
\text { Budget 2017 } \\
\text { (material } \\
\text { costs) }\end{array}$ & Salaries & Total Planned & $\begin{array}{l}\text { Annual Budget } \\
\text { (material costs) } \\
2017^{2}\end{array}$ & Total Annual \\
\hline $\begin{array}{l}\text { PI Home for infants and small } \\
\text { children - Bitola }\end{array}$ & 15.105 .200 & 17.905 .380 & 33.010 .580 & 8.772 .576 & 26.677 .956 \\
\hline $\begin{array}{l}\text { PI for Children without Parents } \\
\text { and Parental Care "11th of } \\
\text { October" - Skopje }\end{array}$ & 13.751 .270 & 14.643 .408 & 28.394 .678 & 7.687 .808 & 22.331 .216 \\
\hline $\begin{array}{l}\text { PI for Children with Upbringing } \\
\text { and Social Problems and } \\
\text { Children with Behavioral } \\
\text { Problems - Skopje }\end{array}$ & 20.024 .000 & 17.150 .580 & 37.174 .580 & 13.872 .540 & 31.023 .120 \\
\cline { 2 - 6 }
\end{tabular}

Table 9: Planned budget expenses for social services 2016-2017

\begin{tabular}{l|l|l|l|l|l|l|l|}
\cline { 2 - 7 } Year & \multicolumn{2}{|l|}{$\begin{array}{l}\text { Sub-program 41 - Daily centers and homes for } \\
\text { social protection outside the institutions }\end{array}$} & \multicolumn{4}{l|}{ Sub-program 42 - Institutions for institutional social protection } \\
\hline & $\begin{array}{l}\text { from the main } \\
\text { budget }\end{array}$ & $\begin{array}{l}\text { self-financing } \\
\text { activities }\end{array}$ & donations & $\begin{array}{l}\text { from the main } \\
\text { budget }\end{array}$ & $\begin{array}{l}\text { funds from } \\
\text { main budget } \\
\text { (income) }\end{array}$ & $\begin{array}{l}\text { self-financing } \\
\text { activities }\end{array}$ & donations \\
\hline 2016 & 95.391 .000 & 2.060 .000 & 2.700 .000 & 236.921 .000 & 19.900 .000 & 50.350 .000 & 3.500 .000 \\
\hline 2017 & 97.723 .000 & 2.060 .000 & 835.000 & 214.792 .000 & 20.000 .000 & 50.350 .000 & 2.650 .000 \\
\hline
\end{tabular}

The small group foster home for children without parents functions as a separate organizational unit within the PI MCSW Berovo. The budget funds are provided for the costs of placement and care for children as well as for maintenance of the building.

The Budget calculation for the small group home in 2016 is 2.462 .280 MKD, allocated for the following items:

Travel and daily costs

Communal services, hating, communication and transport

Materials and small inventory

Repairs and maintenance

Services according to contracts

Other costs - purchase of machines and equipment

\section{Budget expenditures for foster family care givers}

The Law on social protection envisages the right to placement in foster care as a non-residential form of protection to be executed through the CSW. This entitlement is designed for persons with inadequate living conditions or in need of placement when other forms of protection are not available. Foster care placement is regulated through a contract signed between the foster family and the CSW, and outlines key roles, rights and responsibilities for the foster family, as well as regulations concerning contract termination or extension. The CSW is responsible for monitoring and coordinating activities linked to placement and care of a foster child once placed. Foster families are obligated to act according to the contract

${ }^{1}$ Refferes to calculations regarding the expencess needed for the acitivities of the institution calculated by the MLSP.

${ }^{2}$ Reffers to expenses approved by the MF and published in the Official Gazzete. 
with the CSW and duly inform the CSW of significant changes or needs of the foster child. The foster care rulebook specifically regulates criteria for selection of foster families, type and number of beneficiaries, and social protection services. The rulebook specifies the exact amount of allowances for placement and foster care and identifies categories of service beneficiaries eligible for foster care protection. The placement of younger children in foster care is usually related to complex problems in the home. The multi-faceted nature of these problems can make it difficult to isolate the primary cause for each individual placement in foster care for younger children. Often, a specific crisis precipitates the need for foster care placement. Evidence indicates that prior to foster care placement, many biological families were surviving at only marginally functional levels, coping with numerous problems and stress. Overlapping challenges make it difficult for child protection agencies to separate categories of children by problem groups to assist in identifying the most appropriate placements. The rulebook, prepared by the MLSP in cooperation with ISA, provides a legal basis to guide foster care placement and differentiates the following categories of children/persons that may be placed in foster care:

- child without parents and parental care

- child with educational challenges combined with abuse, neglect, and social insecurity

- child with a social behavior

- person with mild and moderate intellectual disability

- person with severe intellectual disability

- person with permanent physical disability

- older person

-adult person with physical and intellectual disability who is not in position to take care of him/herself

Table 10: Data on foster families for the period 2014-2017

\begin{tabular}{l|llll|} 
Year & 2014 & 2015 & 2016 & 2017 \\
\hline Number of foster families & 182 & 190 & 201 & 203 \\
Number of specialized foster families & & & 1 & 1 \\
Number of people placed in foster families & 276 & 288 & 296 & 301 \\
Number of children placed in foster families & 268 & 279 & 288 & 294 \\
Number of children with special needs placed in a foster family & 93 & 98 & 102 & 104
\end{tabular}

The foster family receives a monthly compensation for the costs for the child and compensation for the care. The Law on amendments on the Law on social protection increased the amount of compensation for the costs for a fostered person and the compensation for care provided for 25\% calculated from June 2015.

Table 11: Compensation amounts, per category of persons in foster care (The values are given in denars)

\begin{tabular}{l} 
Category of person \\
child without parents and parental care and a child aged up to \\
6 years \\
\hline A child without parents and parental care and a child aged 6 \\
years and older \\
child with educational and social problems \\
\hline child with bad behavior \\
\hline person mild or heavy mental disabilities as well as a person \\
referred for work qualification \\
\hline person with the worst difficulties in the mental development, \\
person with permanent disability
\end{tabular}

\begin{tabular}{|l|l|l|}
\hline $\begin{array}{l}\text { compensation for } \\
\text { accommodation }\end{array}$ & $\begin{array}{l}\text { compensation for } \\
\text { care }\end{array}$ & Total \\
\hline 6494 & 1947 & 8441 \\
\hline 7142,00 & 2598 & 9740 \\
\hline 7142,00 & 2598 & 9740 \\
\hline 7792.00 & 3247 & 11039.00 \\
\hline 7792.00 & 3247 & 11039.00 \\
\hline 7792.00 & 3247 & 11039.00 \\
\hline
\end{tabular}


The compensation for ad-hock placement of a child in a foster family is $2.000 \mathrm{MKD}$, while the costs for the fostered child and for the care are calculated in accordance with the time duration of the accommodation.

Within the Program for realization of social protection 2017 for the right to compensation for accommodation and compensation for care provided for a person located in a foster family-which will be paid to families that will take care and look after a person - beneficiary of social protection. This right in 2017 is planned to be realized by approximately 180 families that will care for around 290 people, for which 42.000.000 MKD have been planned.

\section{Financing of association of citizens for social services delivery}

Although the legislation provides the basis for involvement of citizen's associations, private practitioners, religious communities and groups and private institutions in the delivery of social services in the country, their share in the provision of residential and non-residential care is considerably smaller and should be further enhanced. There are three levels of financing the associations of citizens for social protection activities:

Governmental program for financing activities of associations and foundations from the state budget on annual basis. The Department for Cooperation with Non-governmental Organizations within the General Secretariat, through its network of civil servants in the ministries responsible for cooperation with civil society organizations, could play a more significant role in terms of supporting these organizations in their social services delivery mission. Despite the well developed supporting legal documents, public calls issued by this Department for provision of financial support to civil organizations should be more publicized and transparent, while funding itself should be increased and based on clear selection, allocation and monitoring criteria.

The Ministry of Labor and Social Policy participates in providing part of the funds for carrying out certain activities of social protection by associations, in a manner and under conditions stipulated in the Law on Social Protection. More detailed determination of the conditions and procedure for allocation of funds to associations of citizens is regulated with the bylaw adopted by the Minister in 2005. However, since guidelines contained in the Rulebook are too general, fair competitive environment and transparent procedure are not always guaranteed, which entails inequality in the treatment and chances for winning the available support. In addition, the grants awarded to registered non-governmental organizations are still insufficient and do not provide possibilities for financial stability and long-term planning of their activities.

Separate source of funding is derived from the Law on Games of Chances and Entertainment Games, income of which is annually distributed mostly to only a few organizations traditionally in receipt of these funds: national disability organizations and their associations, Red Cross of the Republic of Macedonia and sports activities. In the last two years organizations combating domestic violence were also granted part of funds based on the program prepared by the Ministry of Labour and Social Policy. There is no bylaw with clearly prescribed rules and criteria for the amount and manner of allocation of resources. Since these funds are considerable, revision of the list of organizations eligible to access, as well as of the criteria upon which funds are granted, should be carried out.

The analysis of the data on administered grants in the last three years shows that only a small, insignificant part of the budget of the Ministry of Labor and Social Policy is allocated to associations for performing social protection activities. Also, an unbalanced distribution of funds has been noted, with most of the funds being allocated to one association for the realization of the organized living service with support. The lack of clear criteria for funds allocated, the manner of selection of associations and separate amounts by associations, and the very nature of the grant as a financing mechanism, do not give a solid basis for more significant involvement of associations in performance of social protection activities. On the contrary, annual funding creates uncertainty with the service provider in terms of sustainability and continuity of service provision, restricts greater investment in infrastructure and human resources, and provides opportunities for political and other influences and lobbying. This model of registration and financing of associations was a good solution in the initial phase of the development of plural delivery of social services as a first step in bridging the gap between the existing needs for social services and the capacities of non-state social service providers. The analysis indicates that this solution has been outdated in the real circumstances and that conditions have been created for introducing a more complicated scheme for financing social services by non-state actors, which requires a change in the legislation. 


\section{Conclusions and recommendations}

Based on the analysis of total planned budget expenditures for social and child protection for the time 2014-2017, a trend of increased expenditures is evidenced. Basic budget planned expenditures increased from 33.337.320MKD in 2014, to 41.157.473MKD in 2017. In the same period, there is a decrease in funds obtained from fund rising (24.4\%) and loans, and an increase in funds obtained from donations $(87.29 \%)$. When only child protection expenditures are analyzed separately, same trend of decreased planned expenditures for $27.64 \%$ is noticeable for the period 2014-2017. Spending on cash benefits from social and child protection increased for $24.92 \%$, as well as on block grants to local self-government for $22.36 \%$. Unlike cash expenditures, those planned to tackle poverty, reduced for significant $75.35 \%$. Overall, there should be a tendency to restructure the cash benefit scheme (to revise the amount of benefits, to achieve better targeting to the most deserving and to enhance the parallel activities with beneficiaries so as these benefits can serve as a safety-net on a temporary basis) and partially re-allocate funds to support the development of social services for various vulnerable groups, including those in receipt of cash benefits.

Expenditures for child protection rights defined with the Law on Child Protection (parental allowance, child benefit, special allowance, one-off financial assistance for a newborn child and right to participation) evidence significant increase (from 1.917.637MKD in 2014, to 3.045.000MKD in 2016). When the number of beneficiaries of cash benefits is analyzed, there is constant decrease in the number of child supplement beneficiaries due to the restrictive eligibility criteria. Also, child supplement amount is very low. An increase is evident with the beneficiaries of parental allowance for a $3^{\text {rd }}$ child (from 17.671 in 2014, to 23.898 beneficiaries in 2016). Given the fact that amount of parental allowance is higher compared to all the other cash benefits and based on findings from previously carried out researches on child protection benefits, the increase in total child protection expenditures is largely due to the parental allowance for a $3^{\text {rd }}$ child. To ensure financial sustainability of the child protection system, a revision of this benefit is highly recommended.

Institutions are primarily financed by the main budget. Much less funds are provided from donations and self-financing. When annual budgets of the institutions are analyzed (based on data available for PI Home for infants and small children - Bitola, PI for Children without Parents and Parental Care "11th October" - PI for Children with Upbringing and Social Problems and Children with Behavioral Problems - Skopje - Skopje), PI for Children with Upbringing and Social Problems and Children with Behavioral Problems - Skopje has the highest planned annual budget of 37.171.580MKD for 2017, although it accommodates less children than in the other two institutions, where the budget line for salaries exceeds material costs. This calls for a serious in-depth analysis of the functioning, costs of care, institutional and human capacities within the residential placement institutions in Macedonia, in line with the trends towards deinstitutionalization.

Although the legislation provides the basis for involvement of citizen's associations, private practitioners, religious communities and groups and private institutions in the delivery of social services in the country, their share in the provision of residential and non-residential care is considerably smaller and should be further enhanced. It should be emphasized, that despite the formally available support, most of the organizations operate through financial aid from foreign donors (much less from donations by the business sector and individuals), which in turn affects their sustainability.

Subsidies and grants upon announcing public call for project proposals seems to be a dominant model of state/local financing of civil society associations. However, there are other financing mechanisms that could be applied, but for which there is no legislative framework developed in the country yet. The Review below contains recommendations for implementation of possible mechanisms for financing of social services.

\section{Review 1: Mechanisms for financing of social services}

\begin{tabular}{|c|c|c|c|}
\hline Type & Sub-type & Description & Recommendation for implementation* \\
\hline \multicolumn{4}{|c|}{ Existing Mechanisms } \\
\hline $\begin{array}{l}\text { Budget support } \\
\text { mechanisms }\end{array}$ & Subsidies & Direct financial incentives for a service provider & $\begin{array}{l}\text { Exceptionally } \\
\text { (for organizations of special public } \\
\text { interest) }\end{array}$ \\
\hline
\end{tabular}




\begin{tabular}{|c|c|c|c|}
\hline & Grants & $\begin{array}{l}\text { Funds allocated to non-state service providers for } \\
\text { implementation of a specific project, usually on } \\
\text { annual basis (competition based) }\end{array}$ & $\begin{array}{l}\text { On annual basis } \\
\text { (for organizations with innovative } \\
\text { projects) }\end{array}$ \\
\hline \multicolumn{4}{|c|}{ Possible Mechanisms in Future } \\
\hline \multirow[t]{3}{*}{$\begin{array}{l}\text { Social } \\
\text { contracting } \\
\text { (Types of } \\
\text { contracts) }\end{array}$} & $\begin{array}{l}\text { Direct } \\
\text { contracting }\end{array}$ & $\begin{array}{l}\text { Direct negotiations and contracting with existing } \\
\text { service provider (no competitiveness) }\end{array}$ & $\begin{array}{l}\text { Exceptionally } \\
\text { (for organizations recognized for their } \\
\text { service in a situation of lack of other } \\
\text { service providers) }\end{array}$ \\
\hline & Tender & $\begin{array}{l}\text { Service provider is selected based on competitive } \\
\text { procedures with strict criteria regarding the required } \\
\text { social service }\end{array}$ & $\begin{array}{l}\text { Regularly } \\
\text { (for organizations providing services } \\
\text { which are in demand) }\end{array}$ \\
\hline & $\begin{array}{l}\text { Public-private } \\
\text { partnership }\end{array}$ & $\begin{array}{l}\text { Public-private partnership (private partners } \\
\text { implement a for-profit service, previously adjusted } \\
\text { with the governmental objectives or through the } \\
\text { model of co-financing ) }\end{array}$ & $\begin{array}{l}\text { Regularly } \\
\text { (for organizations providing specific } \\
\text { types of services) }\end{array}$ \\
\hline \multirow[t]{4}{*}{$\begin{array}{l}\text { Third-party } \\
\text { payments in } \\
\text { social } \\
\text { contracting } \\
\text { (financial } \\
\text { modalities) }\end{array}$} & $\begin{array}{l}\text { Per capita } \\
\text { (normative } \\
\text { payments) }\end{array}$ & $\begin{array}{l}\text { Institutions are managed by a private provider, } \\
\text { while the government/local self-government } \\
\text { maintains the responsibility for sustainability and } \\
\text { quality of the service through monitoring and } \\
\text { control }\end{array}$ & $\begin{array}{l}\text { Regularly } \\
\text { (for organizations providing mostly } \\
\text { residential type of service) }\end{array}$ \\
\hline & Vouchers & $\begin{array}{l}\text { Partially or fully free of charge usage of social } \\
\text { services based on the choice of the beneficiary } \\
\text { (usually for non-residential care service providers } \\
\text { licensed by the state) }\end{array}$ & $\begin{array}{l}\text { Regularly } \\
\text { (for organizations providing mostly } \\
\text { non-residential type of service) }\end{array}$ \\
\hline & $\begin{array}{l}\text { Fee for } \\
\text { service }\end{array}$ & $\begin{array}{l}\text { A service provider is paid per administered service } \\
\text { delivered to a beneficiary in need referred by a } \\
\text { competent institution. }\end{array}$ & $\begin{array}{l}\text { Occasionally } \\
\text { (for organizations providing specialized } \\
\text { types of services) }\end{array}$ \\
\hline & $\begin{array}{l}\text { Third party } \\
\text { reimbursemen } \\
t\end{array}$ & $\begin{array}{l}\text { Reimbursement for services delivered to a } \\
\text { beneficiary by service provider. }\end{array}$ & $\begin{array}{l}\text { Exceptionally } \\
\text { (for organizations providing specialized } \\
\text { and acute types of services) }\end{array}$ \\
\hline
\end{tabular}

The model of social contracting currently under development, should be further pursued as it is expected to enable decentralization and pluralization of social service delivery on regular basis, contribute towards increased state support to non-governmental organizations and thus to raising the quality, effectiveness and financial and operational stability of social services. This process of introduction of contracting in social protection requires development of regulation for standardization, accreditation and licensing of service providers as pre-conditions for involvement in social service delivery of different stakeholders (NGO's and private sector) through social contracting.

\section{REFERENCES}

[1] Bogoevska Natasha, Trbojevik Svetlana (2017). Analysis of the state legal and budget capacities for financing social services and projects. Skopje: SOS Children's Village Macedonia.

[2] Bogoevska N., Trbojevik S., (2014). Multi-sectorial Collaboration in the Delivery of Social Services in the FYRoM, in Social Economics and Entrepreneurship, (ed) Patricia-Luciana, Runcan and Georgeta Raţă, Cambridge Scholars Publishing

[3] Bogoevska N. et al., (2013). Social Protection System in Macedonia: Centralized Governance versus Decentralization, in Mediterranean Journal of Social Sciences, Special Issue, Vol. 4, No. 11, October 2013, (ed.) Bidzina Savaneli. Rome: MCSER Publishing Rome-Italy

[4] Bogoevska, n., Bornarova, S. (2013). Depth analysis of the social situation of children who have lost or are at risk of losing parental care in the municipalities of the City of Skopje, 2013, Skopje: SOS Children's Village Macedonia

[5] Trajkovska V., at al, (2006) Report: Institutional Assessment of the Responsiveness of Service Providers to violence against Children in Macedonia, UNICEF, Skopje 
[6] Ristovski, P., (2011). Surveillance over subjects and ways of doing it, Skopje: Financial Intelligence Bureau

[7] Constitution of the Republic of Macedonia, Assembly of the Republic of Macedonia, 1991, http://www.sobranie.mk./WBStorage/Files/Ustavna

[8] Rmizmeni.pdf

[9] Family Law - official consolidated text (Official Gazette of the Republic of Macedonia no. 153/14)

[10] Law on Child Protection (Official Gazette of the Republic of Macedonia no. 23/13, 12/14, 44/14, 144/14, 10/15, $25 / 15,27 / 16)$

[11] Law on Justice for Children (Official Gazette of the Republic of Macedonia no. 148/13)

[12] Law on Prevention, Prohibition and Protection Against Domestic Violence (Official Gazette of the Republic of Macedonia no. 138/14, 33/15)

[13] Inheritance law (Official Gazette of the Republic of Macedonia no.47/96)

[14] Law on Local Self-Government (Official Gazette of the Republic of Macedonia no. 5/2002)

[15] Law on Institutions (Official Gazette of the Republic of Macedonia no. 32/2005, 120/2005, 51/2011)

[16] Law on Associations and Foundations (Official Gazette of the Republic of Macedonia no. 52/10, 135/11, $55 / 2016)$

[17] Law on Administrative procedure (Official Gazette of the Republic of Macedonia no. 124/2015)

[18] Law on Equal Opportunities for Men and Women (Official Gazette of the Republic of Macedonia no. 6/12)

[19] Law on Employment and Insurance in Case of Unemployment official consolidated text (Official Gazette of the Republic of Macedonia no. 112/14, 113/14)

[20] Law on Concessions and public private partnership (Official Gazette of the Republic of Macedonia no. 6/2012)

[21] Law on Donations and Sponsorships in Public Activities (Official Gazette of the Republic of Macedonia no. $47 / 200686 / 08$ and 51/2011)

[22] Law on game of chances and entertainment games (Official Gazette of the Republic of Macedonia no. 24/2011, $51 / 2011$ и $148 /$

[23] Rulebook for the way and procedure for awarding resources to citizen's associations for conducting social protection activities (Official Gazette of the Republic of Macedonia no. 24/2005)

[24] Ministry of Finance, Budget of the Republic of Macedonia for 2014, 2015, 2016, 2017. Skopje: Government of the Republic Macedonia. Available on: http://vlada.mk/budzet. Accesed on: 01. 09.2018.

[25] Government of the Republic of Macedonia, Program for realization of the social protection for 2014, 2015, 2016 , 2017, Skopje: Government of the Republic of Macedonia. Available on: http://www.mtsp.gov.mk/dokumenti.nspx. Accesed on: 05. 09.2018. 